\title{
COULOMB LIMIT FOR ACCELERATING CURRENT \\ IN A LINAC ACCELERATING CHANNEL \\ BASED ON COMBINED RF FOCUSING
}

\author{
S.S. Tishkin, M.G. Shulika, O.M. Shulika \\ National Science Center “Kharkov Institute of Physics and Technology”, Kharkiv, Ukraine \\ E-mail: tishkin@kipt.kharkov.ua
}

Ion beam propagation stability in an accelerating channel based on combined RF-focusing (CRFF) at high spacecharge density is investigated. It is demonstrated that in case of grouped beam acceleration, the Coulomb current limitation for both the proton and the heavy ion beam is higher in case of a CRFF-based channel than for an initial part of any modern accelerator based on RFQ focusing.

PACS: 29.17.+w

\section{INTRODUCTION}

When designing a high-power ion linear accelerator, one of the major tasks is to devise a technique for beam focusing that provides strong focusing and is less complicated than focusing by electromagnetic lenses. It should be pointed out that any modern electromagnetic lens is a very complex technological unit requiring its own cooling system and power supply. As an alternative to the external focusing device, a different approach implying that the accelerating rf field provides stability of charged particle beam propagation is proposed (see Refs. [1 - 7]).

However, despite being promising, rf-based focusing is implemented mainly in an initial accelerator section where energy level is low and almost never in mediumenergy one. The only active linear accelerator operating without any external electromagnetic focusing devices is the proton injector URAL-30 which was put into service at the Institute of High-Energy Physics (Russia) in 1981 [8]. A modified version of the alternating phase focusing method (see Refs. $[4,6]$ ) combined with the rf quadrupole focusing technique (see Ref. [1]) when accelerating proton and heavy-ion beams at medium energy is described in Ref. [9].

As for beam propagation stability in both longitudinal and transverse direction in an ion linac accelerating channel which is based on CRFF, the issue is addressed in Ref. [10]. There the values for RFQ field gradient to provide transverse propagation stability for all the particles in an acceleration mode are calculated. It is also shown that such gradients could be achieved in quadrupole gaps considering electrical strength of the electrodes.

Further improvements on the multi-charged ion linear accelerator (MILAC) (see Ref. [11]) such as replacement of grid and magnetic quadrupole focusing for CRFF are presented in Refs. $[12,13]$. Design, layout, and adjustment procedures for interdigital IH accelerating CRFF-based structures are discussed in Ref. [14].

This paper objective is to substantiate the possibility of stable acceleration of intense charge-particle beams in a CRFF-based accelerating structure at medium energy.

\section{MATHEMATICAL MODEL. GENERAL EQUATIONS}

Notice that at medium energy a beam of charged particles is grouped and could be described as a dense triaxial elliptic bunch that generates Coulomb fields with the following components (see Ref. [15]):

$$
\begin{gathered}
E_{s x}=\frac{3 I \lambda(1-f)}{4 \pi \varepsilon_{0} c\left(r_{x}+r_{y}\right) r_{z}} \frac{x}{r_{x}} ; \\
E_{s y}=\frac{3 I \lambda(1-f)}{4 \pi \varepsilon_{0} c\left(r_{x}+r_{y}\right) r_{z}} \frac{y}{r_{y}} ; \\
E_{s z}=\frac{3 I \lambda f}{4 \pi \varepsilon_{0} c r_{x} r_{y}} \frac{z}{r_{z}} .
\end{gathered}
$$

Here $I$ is the beam current over RF period; $\lambda$ is the operating wavelength; $f$ stands for the ellipsoid formfactor; $\varepsilon_{0}$ is the permittivity of free space; $c$ is the speed of light in vacuum; $r_{x}, r_{y}$, and $r_{z}$ are the ellipsoid axes in a laboratory system of coordinates. The form-factor $f$ depends on the ellipsoid form via parameter $p=\gamma r_{z} / \sqrt{r_{x} r_{y}}, \gamma=1 / \sqrt{1-\beta^{2}}, \beta=v / c$ is the relative velocity of the reference particle; $v$ is the reference particle velocity. At $p=1$ the bunch is spherical. At $0.8<p<5.0$ the form-factor could be approximated as $f=1 / 3 p$.

According to Ref. [16], for the above-mentioned beam approximation model the maximum longitudinal and transverse current are expressed respectively as

$$
\begin{gathered}
I_{l, \text { max }}=\frac{2 \mu_{l} \beta \gamma a E_{0} T \sin \left(-\varphi_{s}\right)\left|\varphi_{s}\right|^{2}}{Z_{0} \sqrt{\psi}}, \\
I_{T, \max }=\mu_{T} \frac{4 \pi \varepsilon_{0} \gamma^{3} \beta^{2} m c^{3}\left(r_{x}+r_{y}\right) r_{x} r_{z}}{q \lambda(1-f)}\left(\frac{\sigma_{0}}{P}\right)^{2} .
\end{gathered}
$$

Here the phase extent is $2\left|\varphi_{s}\right|\left(\varphi_{s}\right.$ being the reference particle phase); $r_{z}=\left|\varphi_{s}\right| \beta \lambda / 2 \pi ; \mu_{l}$ and $\mu_{T}$ is the ratio of the longitudinal and transverse component of space charge force to the corresponding focusing force (in case of a high-current beam $\mu_{l} \approx 1$ and $\mu_{T} \approx 1$ ); $a$ is the aperture radius where the beam oscillates; $E_{0} T$ is the amplitude of the equivalent traveling wave; $Z_{0}=1 / \varepsilon_{0} c=376.73 \Omega ; \quad \psi=r_{x, \max } / r_{y, \min } ; \quad r_{x, \max }=a ;$ $\sigma_{0}$ represents the phase shift of radial oscillations over the focusing period at zero current; $q$ stands for the particle charge; $P=N \beta \lambda$ is the focusing period length; $N$ is the integer number. 


\section{RESULTS AND DISCUSSION}

Let us estimate the maximum current in a channel for two CRFF-based linear accelerators, namely, a proton linac for electronuclear studies and a heavy-ion accelerator for radiative and nuclear physics research, the latter operating at the mass-to-charge ratio $A / q=20$. Due to the fact that the Coulomb force influence on beam dynamics is maximal at low particle velocities, it is suffice to take into consideration only initial section of these accelerating structures.

First, we calculate using Eqs. (2), (3) the maximum current in case of proton linac taking into consideration the following parameters: the injection energy is $3 \mathrm{MeV}$; the magnitude of the equivalent traveling wave is $75 \mathrm{kV} / \mathrm{cm}$; the aperture radius $a=0.6 \mathrm{~cm}$; the ellipsoid semiaxes ratio $\psi=r_{x, \text { max }} / r_{y, \text { min }}=2$; the reference particle phase in the axisymmetrical gap $\varphi_{s}=-17.5^{\circ}$, the phase extent $2\left|\varphi_{s}\right|=35^{\circ}$; the phase shift of radial oscillations over the focusing period at zero current $\sigma_{0}=45^{\circ}$. Thus, for the maximum longitudinal and radial current we obtain

$$
I_{l, \text { max }}=385 \mathrm{~mA}, \quad I_{T, \text { max }}=383 \mathrm{~mA} .
$$

As for the case of heavy-ion $(A / q=20)$ linear accelerator, the above-mentioned parameters are almost identical: the injection energy is $2 \mathrm{MeV}$; the magnitude of the equivalent traveling wave is $40 \mathrm{kV} / \mathrm{cm}$; the aperture radius $a=0.7 \mathrm{~cm}$; the ellipsoid semiaxes ratio $\psi=r_{x, \text { max }} / r_{y, \text { min }}=2$; the reference particle phase in the axisymmetrical gap $\varphi_{s}=-17.5^{\circ}$, the phase extent $2\left|\varphi_{s}\right|=35^{\circ}$; the phase shift of radial oscillations over the focusing period at zero current $\sigma_{0}=45^{\circ}$. So, the Eqs. (2) and (3) yield the following values

$$
I_{l, \text { max }}=37 \mathrm{~mA}, \quad I_{T, \text { max }}=22 \mathrm{~mA},
$$

for the maximum longitudinal and transverse current respectively.

Note that due to complexity of the task, several simplifications have been introduced. Therefore, the calculated maximal current, while rough, is higher than the current generated in the initial section of any modern linac. For instance, the maximum current registered in the RFQ-structure is in the range of $100 \ldots 150 \mathrm{~mA}$ for the proton linac and $5 \ldots 15 \mathrm{~mA}$ for the heavy-ion $(A / q=20)$ accelerator.

Figure presents the beam envelops calculated with the help of Trace-3D code (see Ref. [17]). This code was developed by Los Alamos Accelerator Code Group of Los Alamos National Laboratory. It calculates the envelop evolution of a channel-consistent beam through a focusing section with the space-charge force being accounted for. As the program is interactive and has several user-defined options, we used the following approximations: a particle bunch is represented as a triaxial ellipsoid; a gap action is considered in the approximation of a thin lens.

In the figure, the following notations are used: RFQ - a quadrupole section, $\mathrm{G}$ - an axisymmetrical gap center. The beam envelop in the horizontal direction (see Figure, blue solid line) corresponds to the focusing section with the pattern DOOOFFOOOD (with D being the defocusing segment, $\mathrm{O}$ standing for the axisymmetrical gap, and F representing the focusing cell), while the pattern corresponding to the beam envelop in the vertical direction (see Figure, red dashed line) is FOOODDOOOF.

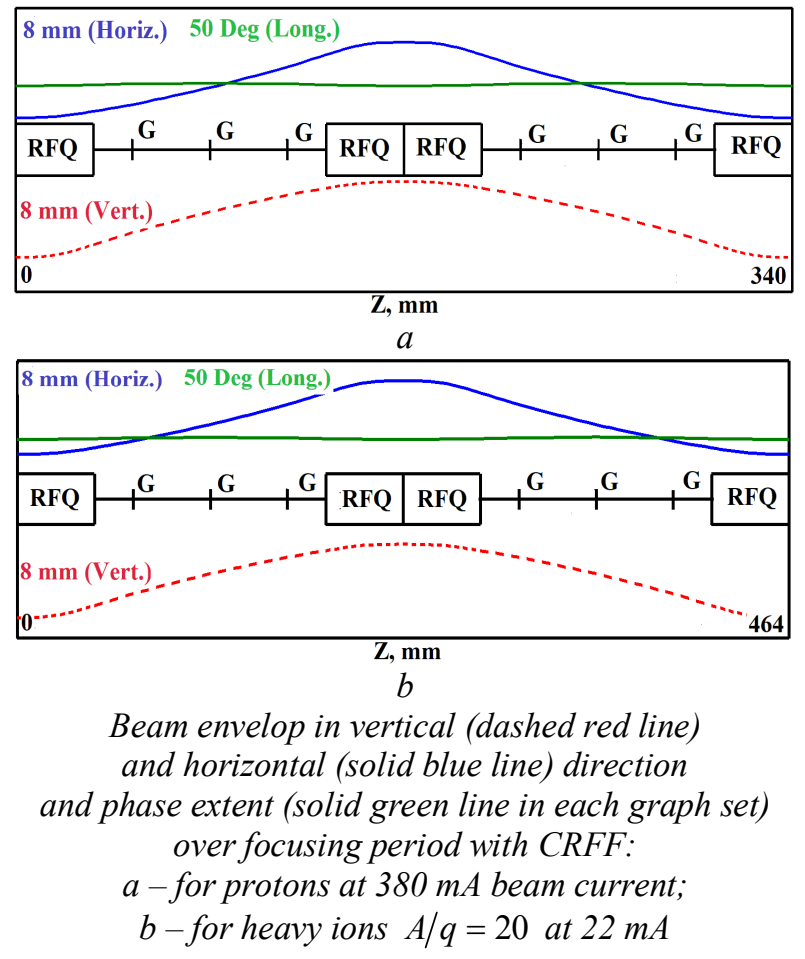

\section{CONCLUSIONS}

The focusing method suggested allows one to capture and steadily accelerate both light and heavy particle beams inside the initial part of any modern accelerator. Also, contrary to focusing by magnetic lenses, rigidity of CRFF does not depend on particle velocity thus enabling CRFF to be implemented into the low-outputenergy initial part of accelerator and in doing so to simplify heavy ion focusing.

\section{REFERENCES}

1. V.V. Vladimirsky. Variant hard focusing in linear accelerator // PTE. 1956, № 3, p. 35-36.

2. M.L. Good. Phase-Reversal focusing in Linear Accelerators // Phys. Rev. 1953, № 2, p. 538.

3. Ya.B. Fainberg. Alternating phase focusing // Proc. of Intern. Symposium on High Energy Accelerators and Pion Physics. Geneva: CERN, 1956, v. 1, p. 91.

4. V.G. Papkovich, N.A. Khizhnyak, N.G. Shulika. Alternating phase focusing in a linear ion accelerator // Problems of Atomic Science and Technology. 1978, № 2, p. 51-56.

5. V.O. Bomko, Z.E. Ptukhina, S.S. Tishkin, N.G. Shulika. Variant of focusing by an accelerating RF field in linear ion accelerators // Proc. RUPAC2002. Obninsk, 2002, v. 1, p. 227-230.

6. V.A. Bomko, A.P. Kobets, Z.E. Ptukhina, S.S. Tishkin. Variant alternation phase focusing with step change of the synchronous phase // Problems of 
Atomic Science and Technology. Series "Nuclear Physics Investigations”. 2004, № 2, p. 153-154.

7. V.O. Bomko, Z.O. Ptukhina, S.S. Tishkin. Variant of the accelerating and focusing structure of the high current linear ion accelerator // Problems of Atomic Science and Technology. Series "Nuclear Physics Investigations”. 2006, № 2, p. 163-165.

8. A.A. Yegorov, V.A. Zenin, S.A. Ilinsky. Launch of Ural-30 Linear accelerator // Zhurnal Tekhnicheskoi Fiziki. 1981, v. 51, p. 1643-1647 (in Russian).

9. S.S. Tishkin. Combined focusing by RF-field for ion linac accelerators // Journal of Kharkiv National University. Physical Series "Nuclear, Particle, Fields”. 2008, № 808, Issue 2(38), p. 37-46.

10. S.S. Tishkin, M.G. Shulika, O.M. Shulika. Ion beam propagation stability in a linac accelerating channel with combined rf focusing // Problems of Atomic Science and Technology. Series "Nuclear Physics Investigations”. 2019, № 6, p. 94-99.

11. V.O. Bomko, O.F. Dyachenko, Ye.V. Ivakhno, et al. New prestripping section of the MILAC linear accelerator designed for accelerating a high current beam of light ions // Proc. of EPAC 2006 Edinburgh, Scotland. 2006, p. 1627-1629.
12. S.S. Tishkin. Accelerating channel for initial section of heavy ion linear accelerator with combined highfrequency focusing // Problems of Atomic Science and Technology. Series "Plasma Electronics and New Methods of Acceleration”. 2008, № 4, p. 327331.

13..B.V. Zajtsev, S.S. Tishkin, M.G. Shulika. The prospects for combined high-frequency focusing usage in high-current heavy ion linacs // Problems of Atomic Science and Technology. Series "Nuclear Physics Investigations”. 2010, № 3, p. 8589.

14. S.S. Tishkin, A.F. Dyachenko, B.V. Zajtsev, et al. Accelerating structure with combined radiofrequency focusing for acceleration of heavy ions A/q $\leq 20$ to energy $1 \mathrm{MeV} / \mathrm{u} / /$ Problems of Atomic Science and Technology. Series "Nuclear Physics Investigations”. 2018, № 3, p. 8-11.

15. P.M. Lapostole. CERN Report AR/Int SG/65-15, 1065.

16. T.P. Wangler. RF linear accelerators. New York: "Wiley", 1998, 382 p.

17. http://www.laacg.lanl.gov/laacg/services/serv_codes. phtml\#trace3d.

Article received 28.01.2020

\section{КУЛОНОВСКИЙ ПРЕДЕЛ УСКОРЯЕМОГО ТОКА В КАНАЛАХ ЛИНЕЙНЫХ УСКОРИТЕЛЕЙ ИОНОВ С КОМБИНИРОВАННОЙ ВЫСОКОЧАСТОТНОЙ ФОКУСИРОВКОЙ}

\section{С.С. Тишкин, Н.Г. Шулика, О.Н. Шулика}

Изучена устойчивость движения ионных пучков в ускоряющих каналах с комбинированной высокочастотной фокусировкой (КВЧФ) при большой плотности пространственного заряда. Показано, что для канала в КВЧФ-структуре, предназначенного для ускорения сгруппированных пучков, кулоновский предел ускоряемого тока как для протонов, так и для тяжелых ионов превышает токи, получаемые в современных линейных ускорителях в начальной части при помощи пространственно-однородной квадрупольной фокусировки.

\section{КУЛОНІВСЬКИЙ ПОРІГ СТРУМУ, ЩО ПРИСКОРЮЄТЬСЯ, У КАНАЛАХ ЛІНІЙНИХ ПРИСКОРЮВАЧІВ 3 КОМБІНОВАНИМ ВИСОКОЧАСТОТНИМ ФОКУСУВАННЯМ}

\section{С.С. Тішкін, М.Г. Шуліка, О.М. Шуліка}

Досліджено стійкість руху іонних пучків у каналах, що прискорюють, з комбінованим високочастотним фокусуванням (КВЧФ) при великій густині просторового заряду. Показано, що для каналу в КВЧФструктурі, який призначено для прискорення згрупованих пучків, кулонівський поріг струму, що прискорюється, для протонів та важких іонів перевищує струми, які отримані в сучасних лінійних прискорювачах у початковій частині за допомогою просторово-однорідного квадрупольного фокусування. 